Вопросы языкознания 2013-2023

ISSN 2079-8784

URL - $\underline{\text { http://ras.jes.su }}$

Все права защищены

Номер 5 Том . 2018

\title{
Рецензия на: D. Smakman, P. Heinrich (eds.). Urban sociolinguistics: The city as a linguistic process and experience. London: Routledge, 2018
}

\section{Мазурова Юлия Викторовна}

Институт языкознания РАН

Москва, Россия

Зубалов Денис Юрьевич

Национальный исследовательский университет «Высшая школа экономики» Москва, Россия

\section{Аннотация}

\section{Ключевые слова:}

Дата публикации: 08.10.2018

Ссылка для цитирования:

Мазурова Ю. В. , Зубалов Д. Ю. Рецензия на: D. Smakman, Р. Heinrich (eds.). Urban sociolinguistics: The city as a linguistic process and experience. London: Routledge, 2018 // Вопросы языкознания - 2018. - Номер 5 С. 155-161 [Электронный ресурс]. URL: http://ras.jes.su/vopjaz/s207987840000642-5-1 (дата обращения: 26.04.2023). DOI: $10.31857 / \mathrm{S} 0373658 X 0001405-4$

Подписки не найдены 
1. Ларин 1928 - Ларин Б. А. О лингвистическом изучении города // Щерба Л. В. (ред.). Русская речь: сборник статей. Вып. 3. Л.: ACADEMIA, 1928. С. 61-75.

2. Blommaert 2010 - Blommaert J. The sociolinguistics of globalization. Cambridge: Cambridge Univ. Press, 2010.

3. Blommaert 2013 - Blommaert J. Complexity, accent, and conviviality: Concluding comments. Applied linguistics. 2013. Vol. 34. No. 5. Pp. 613-622.

4. Bucholtz, Hall 2005 - Bucholtz M., Hall K. Identity and interaction: A sociocultural linguistic approach. Discourse studies. 2005. Vol. 7. No. 4-5. Pp. 585-614.

5. Labov 1966 - Labov W. The social stratification of English in New York. Washington (DC): Center for Applied Linguistics, 1966.

6. Labov 1972 - Labov W. Language in the inner city. Philadelphia: Univ. of Pennsylvania Press, 1972.

7. Trudgill 1974 - Trudgill P. The social differentiation of English in Norwich. Cambridge: Cambridge Univ. Press, 1974.

8. Pennycook, Otsuji 2015 - Pennycook A., Otsuji E. Metrolingualism: Language in the city. London: Routledge, 2015. 


\title{
Review of the book: D. Smakman, P. Heinrich (eds.). Urban sociolinguistics: The city as a linguistic process and experience. London: Routledge, 2018
}

\author{
Yulia Mazurova \\ Institute of Linguistics, Russian Academy of Sciences \\ Moscow, Russia
}

Denis Zubalov

National Research University Higher School of Economics

Moscow, Russia

Abstract

Keywords:

Publication date: 08.10 .2018

Citation link:

Mazurova Y., Zubalov D. Review of the book: D. Smakman, P. Heinrich (eds.). Urban sociolinguistics: The city as a linguistic process and experience. London: Routledge, 2018 // Voprosy Jazykoznanija - 2018. - Issue 5 C. 155-161 [Electronic resource]. URL: http://ras.jes.su/vopjaz/s207987840000642-5-1 (circulation date: 26.04.2023). DOI: $10.31857 / \mathrm{S} 0373658 X 0001405-4$

Код пользователя: 0; Дата выгрузки: 26.04.2023; URL - http://ras.jes.su/vopjaz/s207987840000642-5-1 Bce права защищены. 